\title{
FAKTOR-FAKTOR YANG MEMPENGARUHI KUNJUNGAN WISATA KAMPUNG TEMATIK KOTA TANGERANG
}

\begin{abstract}
ABSTRAK
Penelitian ini bertujuan untuk mengetahui faktor-faktor yang mempengaruhi kunjungan wisata ke kampung tematik di Kota

Asep Ferry Bastian

Tangerang. Penelitian ini bersifat deskriptif dengan pendekatan penelitian survei. Populasi di dalam penelitian ini adalah pengunjung wisata di 15 lokasi kampung tematik dengan sampel sebesar 46 orang. Teknik sampling yang digunakan non probability

${ }^{1}$ Universitas Islam Syekh melalui pendekatan accidental sampling. Hasil penelitian menunjukkan bahwa aspek demografi, tingkat pengenalan pengunjung, faktor pendorong berkunjung dan perilaku pengunjung merupakan faktor-faktor yang dapat mempengaruhi kunjungan wisata ke kampung tematik di Kota Tangerang. email:

a.ferry.bastian@unis.ac.i $\underline{\mathrm{d}}$
\end{abstract}

Kata Kunci: Kampung Tematik, Wisata, Kota Tangerang

\section{A. PENDAHULUAN}

Sektor pariwisata memiliki peranan penting dalam menarik banyak tenaga kerja. Di Indonesia, sektor pariwisata termasuk salah satu dari 11 pekerjaan yang paling banyak menyerap tenaga kerja. Pada tahun 2015 sektor pariwisata menyumbang 10\% dari total GDP Indonesia dengan jumlah nominal tertinggi di ASEAN. Pada awal tahun 2016 secara resmi dimulai ASEAN Economic Community (AEC) yang merupakan kerja sama untuk peningkatan kinerja ekonomi, politik, dan budaya 10 negara ASEAN (Sabon, et al., 2018).

Di dalam pembangunan perekonomian suatu negara pariwisata menjadi penyumbang devisa negara, baik itu negara berkembang ataupun negara maju. Dibandingkan dengan negara-negara ASEAN lainya, potensi pariwisata Indonesia paling banyak, namun dalam prasarana penunjang pariwisata Indonesia masih tertinggal di bawah Thailand, Singapura, dan Malaysia. Kondisi ini mempengaruhi kunjungan wisatawan asing ke Indonesia (Deni \& Sopian, 2017).

Jumlah kunjungan wisatawan mancanegara (wisman) ke Indonesia dalam kurun waktu lima tahun terakhir menunjukkan trend meningkat. Jumlah kunjungan wisman selama 2019 merupakan yang tertinggi dalam periode tersebut. Selama 2019 jumlah kunjungan wisman mencapai 16,11 juta kunjungan atau naik 1,88 persen dibanding jumlah kunjungan selama 2018 yang tercatat 15,81 juta kunjungan (BPS, 2019). Salah satu destinasi utama dari wisatawan mancanegara ke Indonesia adalah Pulau Bali. Bali menjadi tujuan utama wisatawan karena daya tarik keindahan alam dan budayanya, selain itu tujuan lain turis datang ke Bali adalah untuk MICE (meeting, incentive, conference, exhibition), serta bisnis (Sabon, et al., 2018).

Kegiatan pariwisata adalah kegiatan yang terkait dengan usaha untuk memenuhi kebutuhan hidup manusia guna memperoleh kesenangan. Kesenangan itu dinikmati berkat adanya jasa yang diberikan oleh pihak tertentu. Pariwisata itu sendiri adalah sebuah industri (Hakim, 2010). Industri pariwisata sangat jelas 
membantu meningkatkan kesejahteraan masyarakat, bahkan mendorong tumbuhnya ekonomi produktif di masyarakat, dan dapat membuka peluang berbagai jenis usaha seperti usaha penginapan, katering, kerajinan, dan lain-lain (Resnawaty, 2016).

Atas dasar itu, pemerintah Indonesia melalui Kementerian Pariwisata dan Ekonomi Kreatif memiliki agenda kerja di dalam mengembangkan 10 destinasi utama pariwisata di Indonesia. Pemerintah juga telah memiliki perencanaan terintegrasi antar lembaga kementerian yang di gulirkan sejak tahun 2016. Hal ini penting disinergikan sebab pengembangan destinasi wisata selain bertujuan untuk meningkatkan wisman, juga untuk meningkatkan devisa secara optimal (Sabon, et al., 2018).

Pembangunan nasional dan daerah bisa dilakukan apabila ada peningkatan pertumbuhan ekonomi. Kegiatan meningkatkan pertumbuhan ekonomi di daerah bisa bersumber dari Pendapatan Asli Daerah (PAD), yang bisa di gali melalui pengelolaan sumber daya alam (pariwisata) atau sumber daya manusia (Fathorrazi et al., 2019). Sektor industri pariwisata akan memberi dampak linier kepada penerimaan pendapatan suatu daerah dan pendapatan nasional. Maka dari itu, perkembangan pariwisata di Indonesia tidak akan terlepas dari pengembangan pariwisata di daerah (Adityaji, 2018).

Menurut Butowski, (2010) aspek-aspek yang menjadi potensi wisata (pariwisata) itu justru berada di daerah-daerah. Maka dari itu, kecenderungan aset wisata yang dimiliki oleh suatu daerah akan berpengaruh terhadap pembangunan regional dan lokal. Sedangkan pertumbuhan pariwisata yang baik di suatu daerah akan berdampak kepada (faktor) pendorong pembangunan di wilayah tersebut.

Kota Tangerang adalah satu daerah yang fokus terhadap pengembangan destinasi wisata. Hal itu sebagaimana tertuang pada visi Kota Tangerang tahun 2018-2023, yaitu: “Terwujudnya Kota Tangerang yang Sejahtera, Berakhlakul Karimah dan Berdaya Saing". Sebagai upaya di dalam mewujudkan visi tersebut di susun program yang di harapkan dapat bersinergi dan terintegrasi secara baik. Program tersebut adalah Tangerang LIVE yang merupakan akronim dari liveable (kota layak huni), investable (kota layak investasi), visitable (kota layak di kunjungi), dan e-city (kota pintar) (Bastian, 2018).

Sejak tahun 2017 telah dicanangkan program yang berorientasi kampung tematik. Program tersebut sebagaimana tertuang di dalam RPJMD Kota Tangerang 2019-2023 di sebut sebagai program kampung kita. Kampung tematik merupakan ikhtiar dari perwujudan Kota Tangerang sebagai kota yang layak di kunjungi (visitable). Sebagai hulu pemikiran dari lahirnya program tersebut, yakni demi terciptanya tatanan kehidupan masyarakat yang sejahtera di Kota Tangerang.

Kampung tematik diibaratkan sebagai pembangunan yang berorientasi pada pembentukan gagasan, topik yang khas dan unik. Lahir dari gagasan kreatif komunitas maupun masyarakatnya, kampung tematik dapat disebut juga sebuah inovasi sosial. (Kłoczko-Gajewska, 2014). Konsep kampung tematik lebih kepada menawarkan masyarakat untuk terlibat proaktif, sehingga tidak hanya berbasis 
masyarakat akan tetapi juga penciptaan ruang kampung berciri khas yang berkelanjutan oleh masyarakat (Idziak et al., 2015).

Menurut Akbar \& Alfian, (2018) pembangunan kampung-kampung tematik diharapkan bisa menjadi solusi atas kondisi permukiman kumuh yang ada di suatu kota. Dengan berdirinya kampung tematik juga akan mendorong orientasi pembangunan ekonomi khusunya pada sektor pariwisata. Pengembangan kampung-kampung tematik menjadi kampung wisata memiliki tujuan dalam peningkatan taraf hidup masyarakat yang sehat, aman dan nyaman. Untuk mendukung penataan kampung tematik harus dimulai dari perencanaan dan rancangan lanskap kampung bertema khas (Kristiana \& Kusumoarto, 2019).

Sebagaimana dikatakan Fosso \& Kahane, (2013) sebuah konsep pengembangan kampung tematik bisa memperoleh nilai positif jika unsur masyarakatnya bisa turut serta dengan melihat dampak positif, potensi peningkatan kawasan, sampai dengan peluang memiliki pendapatan yang bisa dihasilkan. Ada tiga tahap konsep kampung, yaitu (1) bersama masyarakat mencari ide/gagasan di dalam pengembangan kawasan kampung untuk menciptakan lapangan pekerjaan dengan melibatkan partisipasi masyarakat lokal. (2) menetapkan tema kampung melalui penemuan sekelompok orang yang berminat dan mau bekerjasama merealisasikan ide, gagasan, tema khas di kampungnya. (3) delineasi dan koordinasi gagasan dan tema yang selanjutnya dimodifikasi melalui bermacam-macam aktor yang terlibat sehingga akhirnya di aplikasikan lebih nyata di wilayahnya (Tamara, 2018).

Di Kota Tangerang terdapat 15 kampung tematik, yaitu Kampung Bekelir, Markisa, Hidroponik, Grenpul, Tidar, Batik, KPK, Anggur, ATM, Mural, Harmonis, Hijau Indah Bersih, Talas, Rukun, dan Baca. Kampung tematik didirikan bukan tanpa alasan, melainkan dengan terciptanya kampung tematik dapat menjadi titik awal perbaikan kawasan lingkungan sekaligus untuk mendorong potensi sosial dan pertumbuhan ekonomi di masyarakat (Wismansyah, 2020). Penelitian ini bertujuan untuk mengetahui faktor-faktor yang mempengaruhi kunjungan wisata kampung tematik Kota Tangerang.

\section{Kajian Pustaka}

Pariwisata

Pariwisata di definisikan sebagai teori dan praktik untuk menjadi turis. Ini melibatkan kepergian atau mengunjungi tempat-tempat untuk tujuan rekreasi. Pariwisata terdiri atas ide-ide dan pendapat orang yang membentuk keputusan mereka dalam melakukan perjalanan, tentang ke mana harus pergi (dan tidak pergi ke mana) serta apa yang dilakukan atau tidak dilakukan, tentang bagaimana berinteraksi dengan wisatawan lain, penduduk setempat, dan personil pelayanan (Leiper, 2004).

Menurut Goeldner \& Ritchie (2009) pariwisata dapat didefinisikan sebagai jumlah dari fenomena dan hubungan yang timbul dari interaksi wisatawan, pemasok bisnis, pemerintah setempat, dan masyarakat setempat dalam proses untuk menarik wisatawan dan pengunjung lainnya. Pariwisata merupakan komposisi kegiatan, jasa, dan industri yang menghadirkan pengalaman perjalanan, 
yaitu: transportasi, akomodasi, penyediaan makan dan minum, toko, hiburan, fasilitas kegiatan, dan jasa perhotelan lain yang tersedia untuk individu atau kelompok yang bepergian jauh dari rumah.

Sedangkan menurut Sabon et al., (2018) pengembangan destinasi wisata mempunyai kriteria (1) nilai daya tarik (atraksi) yang berkualitas, (2) kesiapan amenitas pariwisata (infrastruktur dan sarana prasarana pariwisata), (3) aksesbilitas (jaringan moda transportasi dan konektivitas), (4) kesiapan dan dukungan masyarakat dan pemerintah daerah, (5) tata kelola destinasi pariwisata, (6) potensi pengembangan pasar mancanegara dan nusantara.

Inskeep, (1998) menjelaskan jika suatu kawasan wisata akan baik dan berhasil apabila hal-hal mendasar dikerjakan secara optimal, yaitu (1) mempertahankan kelestarian lingkungan, (2) meningkatkan kesejahteraan masyarakat di wilayah kawasan, (3) memberikan kepuasan kepada pengunjung, (4) memadukan unit pembangunan masyarakat di area kawasan pengembangan.

Menurut Vana \& Malaescu, (2016) kepariwisataan dijelaskan sebagai berikut: (1) pengembangan kegiatan pariwisata berdasarkan warisan budaya dapat meningkatkan kesadaran identitas budaya dan kebanggaan daerah. (2) pengembangan kegiatan pariwisata sering dikaitkan dengan daya saing sosial antar kelompok dan konflik atas sumber daya, wisatawan, dan lain-lain. (3) nilai dalam kualitas pengalaman wisata diciptakan dan disampaikan kepada wisatawan dengan sejumlah kerja sama besar dan kolaborasi antara jaringan aktor yang saling berinteraksi. (4) komunitas dengan warisan budaya kuno yang kuat dikaitkan dengan ketegangan atau daya saing antar kelompok yang bersejarah. (5) pemukiman dengan potensi warisan budaya yang tinggi sering kali menyajikan profil budaya sosial-psikologis masyarakat yang kurang menguntungkan untuk kerja sama, sikap menyambut wisatawan, dan inisiatif kewirausahaan.

Kampung Tematik

Kampung tematik merupakan suatu usaha di dalam menata dan mengembangkan kawasan dengan berbasiskan potensi lokal yang unik dan dinamis (Ujianto \& Zahro, 2018). Kreativitas dan partisipasi masyarakat sangat diperlukan dalam menciptakan suatu atraksi baru supaya destinasi wisata kampung tematik tetap eksis secara berkelanjutan (Imran \& Mbulu, 2020). Kampung tematik menjadi strategi di dalam penanggulangan kemiskinan dan dapat meningkatkan kualitas kawasan permukiman perkotaan (Kristiana \& Kusumoarto, 2019)

Di dalam pengembangan program kampung tematik, pemerintah, masyarakat dan akademisi perlu memperhatikan faktor- faktor lain disamping unsur visual, yaitu diantaranya pengontrolan fisik kampung terhadap lingkungan alam di sekitarnya, fungsi ruang dan bangunan yang dirancang di kawasan kampung yang digunakan guna mengakomodir kegiatan warga dan pengunjung, struktur sosial masyarakat serta simbol-simbol budaya yang tertanam dari kehadiran kampung tematik (D. H. Putri \& Pawestri, 2019).

Menurut Bastian, (2019) program kampung tematik bertujuan, yaitu: (1) dapat menjadi solusi atas kemiskinan, dan senantiasa memenuhi kebutuhan dasar rakyat, 
kesenjangan ekonomi, dan mengatasi tingginya angka pengangguran. (2) bisa mendorong pertumbuhan ekonomi skala kecil (lokal), menaikan daya saing UMKM, dan merangsang daya beli masyarakat. (3) mencermati dan menggali peluang potensi ekonomi masyarakat yang berbasis wilayah permukiman sesuai karakteristik demografi masing-masing. (4) meningkatkan kualitas lingkungan tempat tinggal yang bersih, sehat, dan layak di tempati. (5) membangkitkan kesadaran, rasa tanggung jawab, dan sebagai bentuk pemberdayaan masyarakat atas kondisi lingkungan sebagai tempat bermukim dan berhuni. (6) meningkatkan rasa soliditas warga masyarakat melalui semangat kekeluargaan dan gotongroyong di dalam pembangunan wilayah. (7) menciptakan awareness dan branding image suatu kota destinasi pariwisata yang berdaya saing.

Partisipasi dari masyarakat lokal di dalam mengembangkan produk wisata seperti kampung tematik merupakan persyaratan mutlak dalam kepastian berlanjutnya pengembangan pariwisata perkampungan (Adikampana et al., 2019). Kehadiran kampung tematik dapat dipengaruhi dari keselarasan tema yang di tampilkan dengan ciri karakteristik dari kampung tersebut, kematangan konsep dan teknis implementasi, serta keikutsertaan dari masyarakat. (L. Y. Putri \& Pigawati, 2019).

Perilaku Pengunjung Wisata

Perilaku konsumen adalah tindakan-tindakan yang dilakukan oleh individu, kelompok atau organisasi yang berhubungan dengan proses pengambilan keputusan dalam mendapatkan, menggunakan barang-barang atau jasa ekonomis yang dapat dipengaruhi lingkungan (Kotler, 2005).

Menurut Kotler, (2005) ada dua faktor penentu di dalam pengaruh keputusan pembelian konsumen, yaitu faktor lingkungan dan faktor individual: Pertama, faktor lingkungan, seperti: (a) budaya (b) sub budaya (c) kelas sosial (d) kelompok referensi (e) keluarga (f) faktor-faktor situasional (g) nilai-nilai, norma dan peranan sosial (h) variabel-variabel bauran pemasaran. Kedua, faktor individual, yaitu: (a) persepsi (b) motif (c) pengilahan informasi (d) pembelajaran (e) sikap dan keyakinan (f) kepribadian (g) pengalaman (h) konsep diri.

Perilaku wisatawan menunjukkan bahwa motif utamanya, yaitu untuk beristirahat dan melakukan relaksasi, memperkaya pengetahuan dan pengalaman mereka terhadap destinasi wisata yang baru, beraktivitas yang terkait dengan rekreasi, mengembangkan nilai-nilai personal, serta pengalaman berhubungan sosial dengan orang lain (Slabbert, 2015).

Karakterisik perilaku wisatawan yaitu merupakan respon psikologis yang kompleks-yang muncul dalam bentuk perilaku atau tindakan yang khas secara perseorangan yang secara langsung terlibat dalam pengambilan keputusan untuk pembelian produk (dalam kasus ini perjalanan wisata), kemudian saat melakukan perjalanan wisata hingga saat kembali setelah melakukan perjalanan wisata (Wiweka, et al. 2019).

Goeldner \& Ritchie (2009) mengatakan terdapat enam segmen pasar yang menerima berbagai jenis manfaat dari liburan, yaitu: (1) mereka yang menekankan kegembiraan dan pelarian (2) pencari adrenalin (kegembiraan) murni (3) sebuah 
keluarga, dan kelompok yang berorientasi pada teman (4) naturalis (mereka yang menyukai lingkungan alami) (5) kelompok yang menekankan nilai pelarian dengan sendirinya (6) kelompok yang menikmati semuanya manfaat.

\section{B. METODE PENELITIAN}

Jenis penelitian ini adalah penelitian deskriptif (descriptive research), yaitu berupa penelitian dengan tujuan mendeskripsikan dengan jelas dan rinci terkait aspek atau hal-hal relevan atas fenomena di mana menjadi peminatan peneliti (Solimun, et al. 2018).

Tujuan penelitian deskriptif adalah menggambarkan karakteristik atau perilaku suatu populasi dengan cara yang sistematis dan akurat. Hal biasanya, penelitian deskriptif tidak di desain untuk menguji hipotesis, tetapi lebih pada upaya menyediakan informasi seputar karakter fisik, sosial, perilaku, ekonomi, atau psikologi dari sekelompok orang. Jenis penelitian deskriptif yang biasa diterapkan adalah: (1) penelitian survei (2) penelitian demografis (3) penelitian epidemiologis (Vanderstoep, 2009).

Pada penelitian ini digunakan pendekatan penelitian survei yang merupakan penelitian dengan mengumpulkan informasi dari suatu sampel dengan menanyakan melalui angket atau interview supaya nantinya menggambarkan berbagai aspek dari populasi (Fraenkel, et al. 1990). Metode peneletian survei adalah satu bentuk teknik di mana informasi dikumpulkan dari sejumlah sampel berupa orang, melalui pertanyaan-pertanyaan (Zikmund, 1997).

Survei sebenarnya lebih tepat dikatakan sebagai salah satu penelitian deskriptif sebab survei merupakan kegiatan penelitian yang mengumpulkan data pada saat tertentu dengan tiga tujuan penting, yaitu mendeskripsikan keadaan alami; keadaan sekarang untuk dibandingkan; dan menentukan hubungan sesuatu yang hidup diantara kejadian spesifik (Cohen, et al. 2007).

MacMillan \& Schumacher (2001) menyatakan pada penelitian survei, peneliti menyeleksi suatu sampel dari responden dan menggunakan kuesioner atau melakukan interview untuk mengumpulkan informasi terhadap variabel yang menjadi perhatian peneliti. Data yang dikumpulkan kemudian digunakan untuk mendeskripsikan karakteristik dari populasi tertentu.

Penelitian ini berlokasi di 15 titik kampung tematik di Kota Tangerang, yaitu: Kampung Bekelir, Markisa, Hidroponik, Grenpul, Tidar, Batik, KPK, Anggur, ATM, Mural, Harmonis, Hijau Indah Bersih, Talas, Rukun, dan Baca. Yang menjadi populasi adalah pengunjung (wisatawan) yang datang ke kampung tematik dan berkunjung ke salah satu lokasi dari 15 lokasi kampung tematik di Kota Tangerang, pada waktu akhir pekan (weekend) atau hari kerja.

Jumlah populasi di dalam penelitian ini tidak diketahui (infinite population) sebab data jumlah pengunjung ke kampung tematik tidak diketahui secara pasti. Teknik sampling yang digunakan adalah non probability sampling melalui pendekatan teknik accidental sampling, dengan jumlah sampel sebesar 46 orang. Data diperoleh melalui data primer yang diperoleh melalui penyebaran kuesioner dan interview kepada para pengunjung kampung tematik, sedangkan data 
sekunder diperoleh melalui hasil tinjauan pustaka; buku, artikel, jurnal ilmiah nasional dan internasional, website, media massa cetak/online dan media sosial.

Teknik pengumpulan data, yaitu melalui wawancara dengan responden agar mendapatkan informasi terkait fenomena yang diteliti. Wawancara bersifat terstruktur dan bertatap muka, dengan sebelumnya telah menyiapkan daftar pertanyaan. Metode analisis data bersifat deskriptif dengan menggunakan alat analisis SPSS.

\section{Hasil}

Demografi Responden

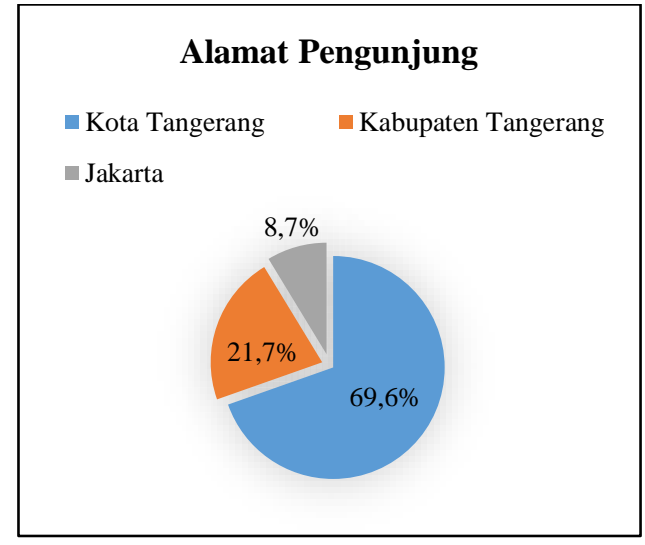

Gambar 1 Alamat Pengunjung

Sumber: Data Primer Diolah Penulis, 2019

Berdasarkan gambar 1 di atas menunjukkan bahwa pengunjung kampung tematik menurut alamat pengunjung paling banyak berasal dari Kota Tangerang, yakni sebesar 69,6 persen. Kemudian pengunjung dari Kabupaten Tangerang sebesar 21,7 persen. Sedangkan wilayah lainnya, yaitu Jakarta sebesar 8,7 persen.



Gambar 2 Jenis Kelamin

Sumber: Data Primer Diolah Penulis, 2019

Berdasarkan gambar 2 di atas dapat di jelaskan bahwa pengunjung kampung tematik untuk kategori jenis kelamin lebih banyak perempuan, yaitu sebesar 54,3 persen, sedangkan pengunjung laki-laki sebanyak 45,7 persen. 


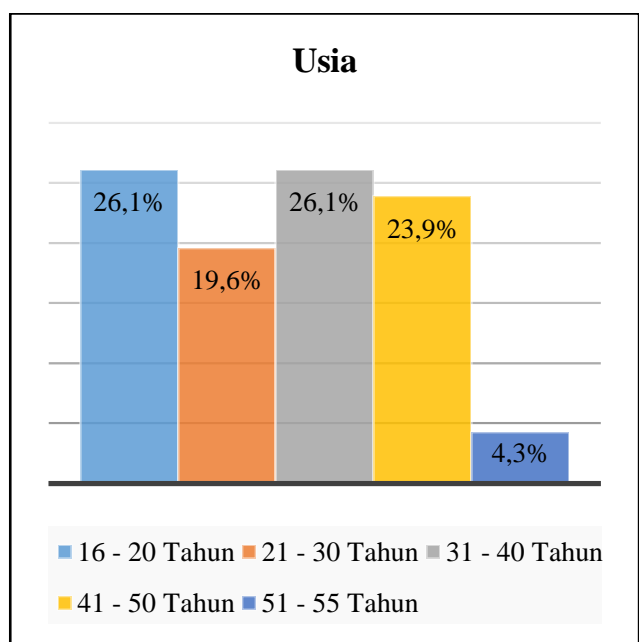

Gambar 3 Usia

Sumber: Data Primer Diolah Penulis, 2019

Berdasarkan gambar 3 di atas memperlihatkan bahwa pengunjung yang datang ke kampung tematik menurut kategori usia paling banyak, yaitu usia antara 16-20 tahun dan 31-40 tahun masing-masing sebesar 26,1 persen, sedangkan usia antara 41-50 tahun sebesar 23,9 persen, usia antara 21-30 sebesar 19,6 persen, dan usia $51-55$ sebesar 4,3 persen.

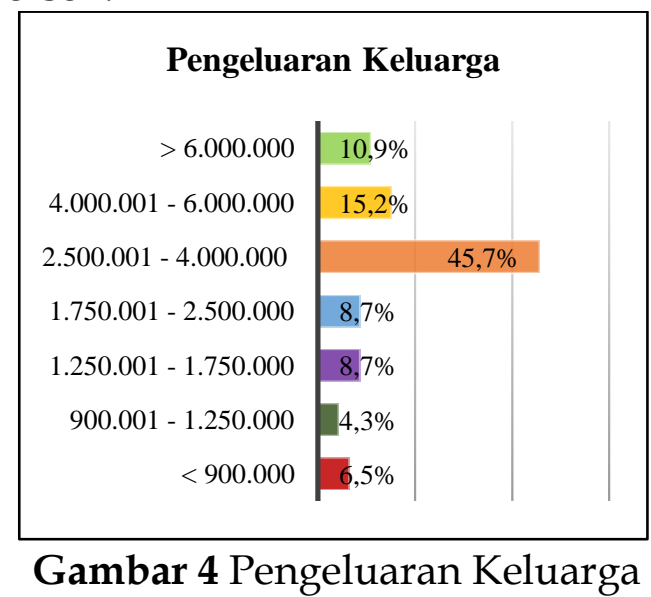

Sumber: Data Primer Diolah Penulis, 2019

Berdasarkan gambar 4 di atas menunjukkan bahwa pengunjung kampung tematik untuk besaran pengeluaran keluarga perbulan paling tinggi, yaitu Rp. 2,500,001-4,000,000 sebesar 45,7 persen. Sedangkan pengeluaran Rp. 4,000,000$6,000,000$ sebesar 15,2 persen, pengeluaran di atas (>) Rp. 6,000,000 sebesar 10,9 persen, pengeluaran Rp. 1,750,001-2,500,000 sebesar 8,7 persen, pengeluaran Rp. 1,250,000-1,750,000 sebesar 8,7 persen, pengeluaran Rp. 9,00,001-1,250,000 sebesar 4,3 persen, dan kurang (<) Rp. 900,000 sebesar Rp. 6,5 persen. 


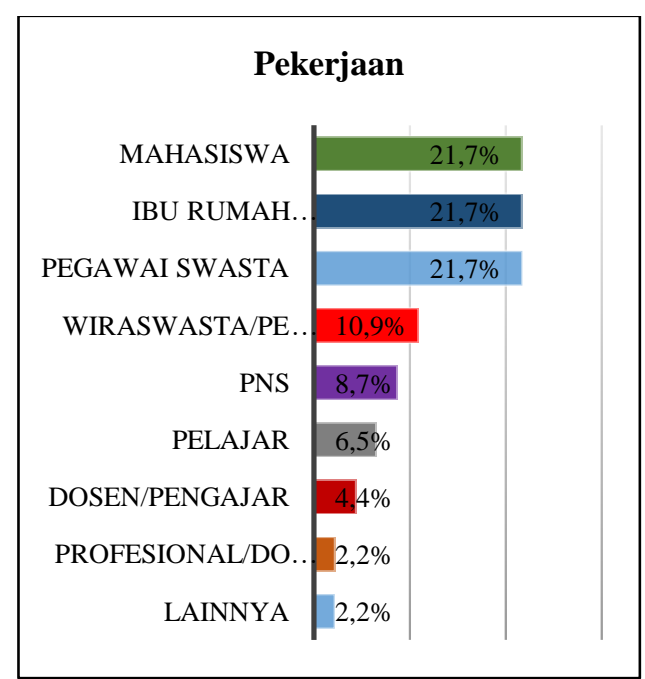

Gambar 5 Pekerjaan

Sumber: Data Primer Diolah Penulis, 2019

Berdasarakan gambar 5 di atas dapat di jelaskan bahwa pengunjung kampung tematik perihal kategori pekerjaan paling banyak adalah mahasiswa, ibu rumah tangga, dan pegawai swasta masing-masing sebesar 21,7 persen. Kemudian (wiraswasta/pengusaha/pedagang) sebesar 10,9 persen, PNS/ASN (Aparatur Sipil Negara) sebesar 8,7 persen, pelajar sebesar 6,5 persen, (dosen/pengajar) 4,4 persen, (profesional/dokter/pengacara) sebesar 2,2 persen, dan pekerjaan lainnya sebesar 2,2 persen.

\section{Pengenalan Pengunjung}

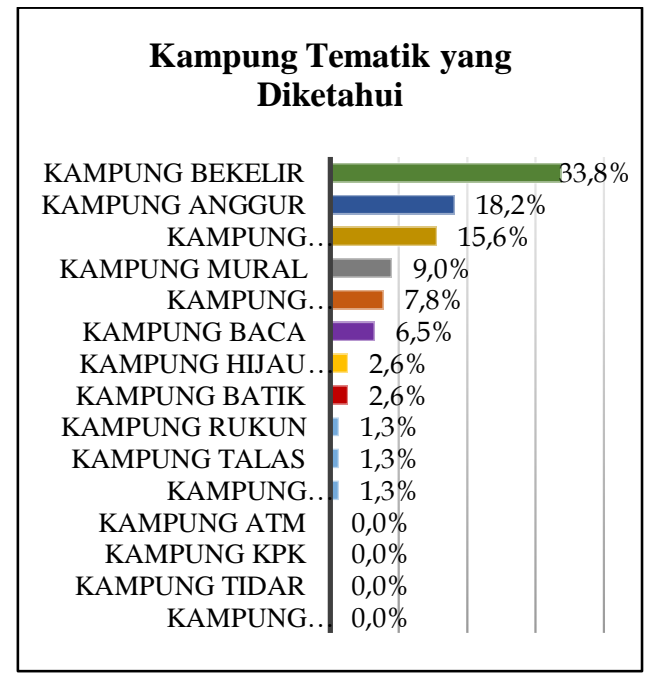

Gambar 6 Kampung Tematik yang Diketahui

Sumber: Data Primer Diolah Penulis, 2019

Berdasarkan gambar 6 di atas memperlihatkan bahwa pengunjung kampung tematik untuk kriteria kampung tematik yang diketahui paling banyak adalah kampung bekelir sebesar 33,8 persen. Kemudian kampung anggur sebanyak 18,2 persen, kampung harmonis sebesar 15,6 persen, kampung mural sebesar 9,0 
persen, kampung markisa sebesar 7,8 persen, kampung baca sebesar 6,5 persen, kampung hijau indah bersih, kampung batik masing-masing sebesar 2,6 persen, kampung rukun, kampung talas, kampung hidroponik masing-masing sebesar 1,3 persen. Sedangkan kampung ATM, kampung KPK, kampung tidar dan kampung grenpul masing-masing sebesar 0,0 persen.

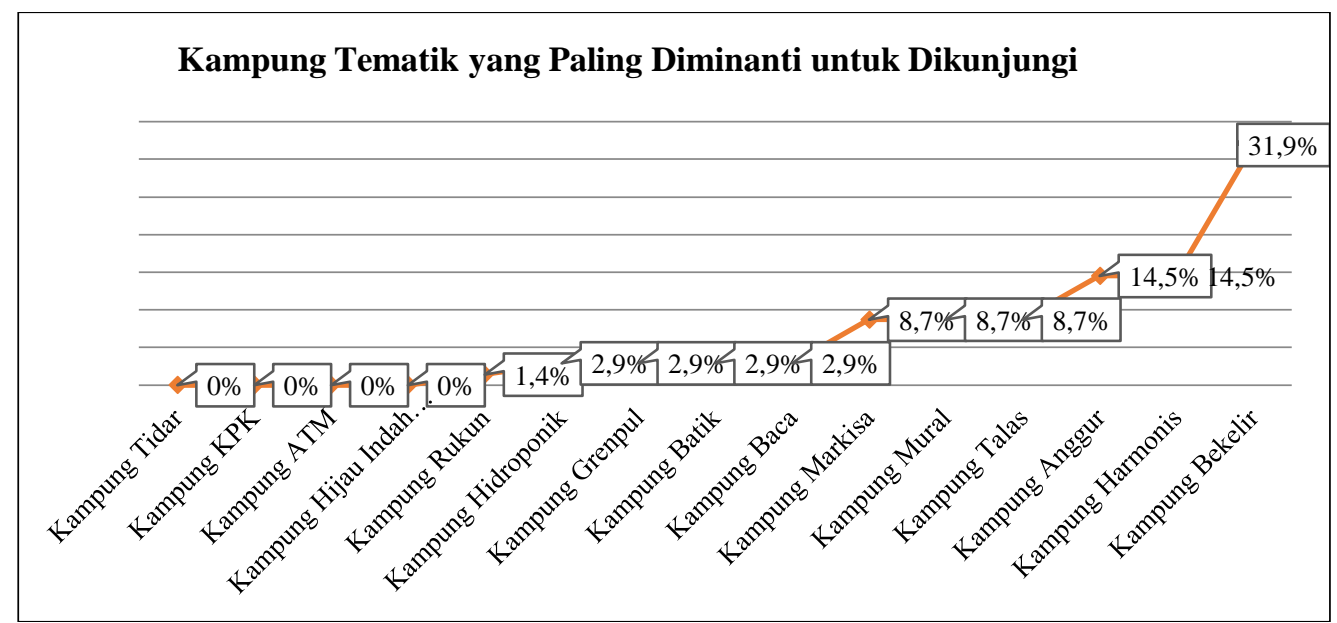

Gambar 7 Kampung Tematik yang Paling Diminanti untuk Dikunjungi

Sumber: Data Primer Diolah Penulis, 2019

Berdasarkan gambar 7 di atas menunjukkan bahwa pengunjung yang datang ke kampung tematik pada kriteria kampung tematik yang diminati untuk dikunjungi paling tertinggi adalah kampung bekelir sebesar 31,9 persen. Kemudian kampung harmonis dan kampung anggur masing-masing sebesar 14,5 persen, kampung talas, kampung mural, kampung markisa masing-masing 8,7 persen, kampung baca, kampung batik, kampung grenpul, kampung hidroponik masingmasing sebesar 2,9 persen, kampung rukun sebesar 1,4 persen, kampung hijau indah bersih, kampung ATM, kampung KPK, kampung tidar masing-masing sebesar 0 persen.

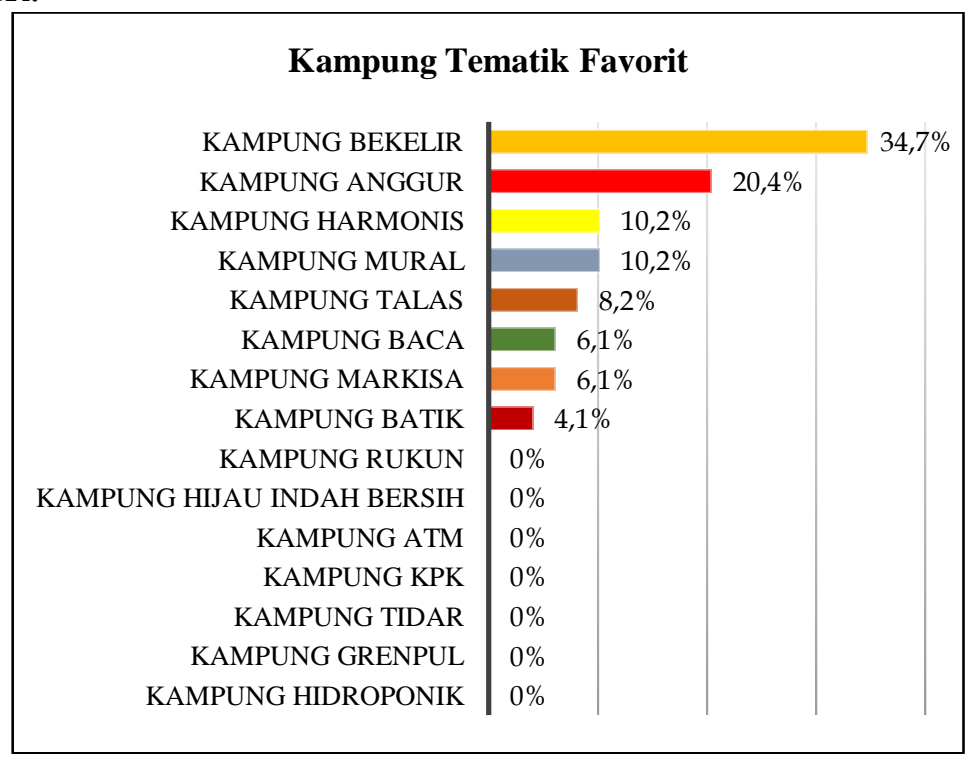

Gambar 8 Kampung Tematik Favorit 
Sumber: Data Primer Diolah Penulis, 2019

Berdasarkan gambar 8 di atas disebutkan bahwa pengunjung kampung tematik pada kriteria kampung tematik favorit yang terbanyak adalah kampung bekelir sebanyak 34,7 persen. Sedangkan kampung anggur sebesar 20,4 persen, kampung harmonis dan kampung mural masing-masing sebesar 10,2 persen, kampung talas sebesar 8,2 persen, kampung baca, kampung markisa masingmasing sebesar 6,1 persen, kampung batik sebesar 4,1 persen. Sementara kampung rukun, kampung hijau indah bersih, kampung ATM, kampung KPK, kampung tidar, kampung grenpul, kampung hidroponik masing-masing sebesar 0 persen.

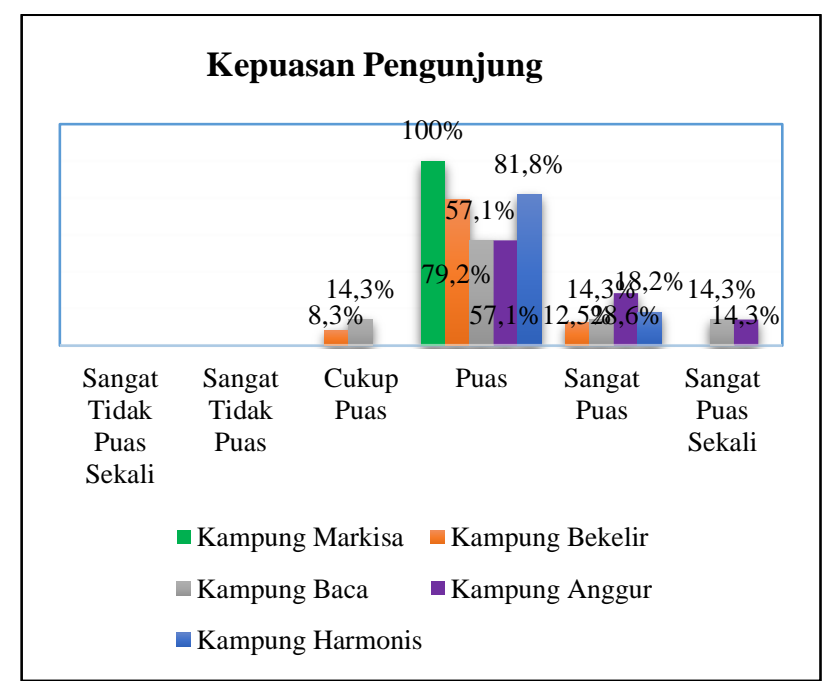

Gambar 9 Kepuasan Pengunjung

Sumber: Data Primer Diolah Penulis, 2019

Berdasarkan gambar 9 di atas dapat di uraikan bahwa pengunjung kampung tematik pada kriteria kepuasan pengunjung yang tertinggi menyatakan puas adalah terhadap kampung markisa sebesar 100 persen. Kemudian yang menyatakan puas terhadap kampung harmonis sebesar 81,8 persen, sangat puas sebesar 18,2 persen. Selanjutnya yang menyatakan puas terhadap kampung bekelir sebesar 79,2, sangat puas sebesar 12,5 persen, cukup puas sebesar 8,3 persen. Sedangkan yang menyatakan puas terhadap kampung baca sebesar 57,1 persen, sangat puas sebesar 14,3 persen, sangat puas sekali sebesar 14,3 persen, cukup puas sebesar 14,3 persen. Sementara yang menyatakan puas terhadap kampung anggur sebesar 57,1 persen, sangat puas sebesar 28,6 persen, sangat puas sekali sebesar 14,3 persen. 


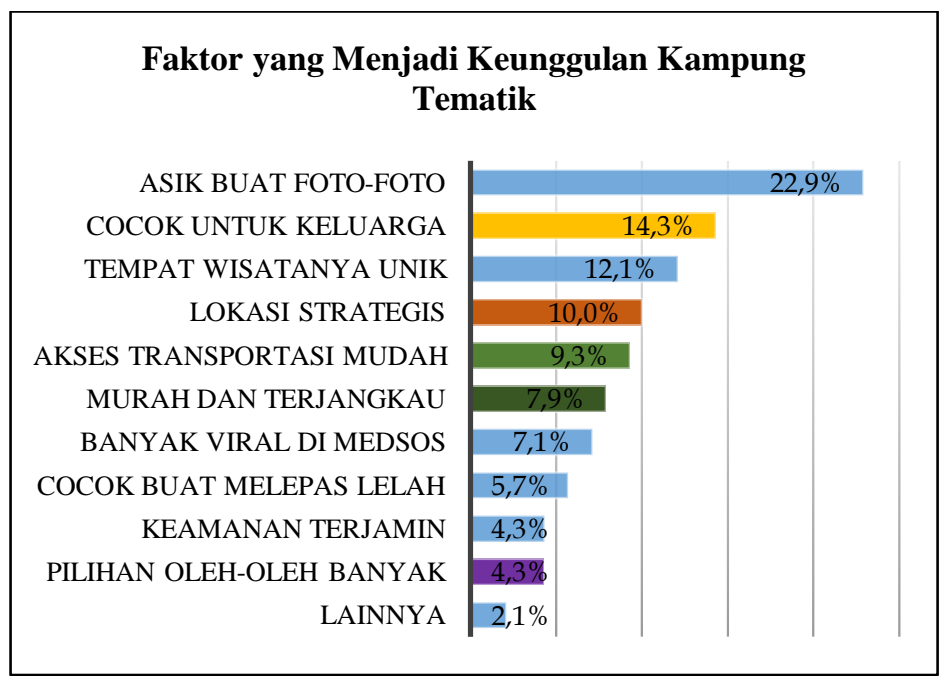

Gambar 10 Faktor yang Menjadi Keunggulan Kampung Tematik Sumber: Data Primer Diolah Penulis, 2019

Berdasarkan gambar $10 \mathrm{di}$ atas memperlihatkan bahwa pengunjung kampung tematik untuk kriteria faktor yang menjadi keunggulan kampung tematik yang paling banyak adalah asik buat foto-foto sebesar 22,9 persen. Kemudian cocok untuk keluarga sebesar 14,3 persen, tempat wisatanya unik sebesar 12,1 persen, lokasi strategis sebesar 10,0 persen, akses transportasi mudah sebesar 9,3 persen, murah dan terjangkau sebesar 7,9 persen, banyak viral di medsos sebesar 7,1 persen, cocok buat melepas lelah sebesar 5,7 persen, keamanan terjamin, pilihan oleh-oleh banyak masing-masing sebesar 4,3 persen, lainnya sebesar 2,1 persen.

Faktor Berkunjung

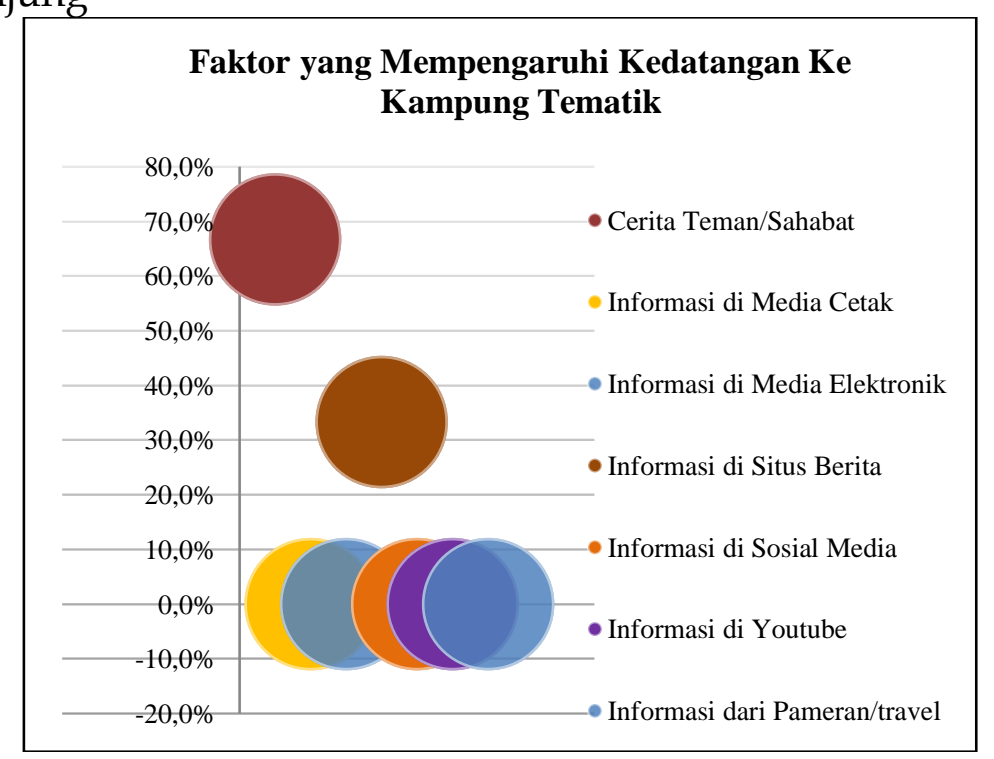

Gambar 11 Faktor yang Mempengaruhi Kedatangan Ke Kampung Tematik Sumber: Data Primer Diolah Penulis, 2019

Berdasarkan gambar 11 di atas bermakna bahwa pengunjung kampung tematik untuk kriteria faktor yang mempengaruhi kedatangan ke kampung 
tematik yang paling tinggi adalah cerita dari teman/sahabat sebesar 66,7 persen. Sedangkan yang berikutnya, yaitu informasi di situs berita sebesar 33,3 persen. Kemudian faktor informasi di media cetak, informasi di media elektronik, informasi di sosial media, informasi di youtube, informasi dari pameran/travel, informasi lainnya masing-masing sebesar 0 persen.

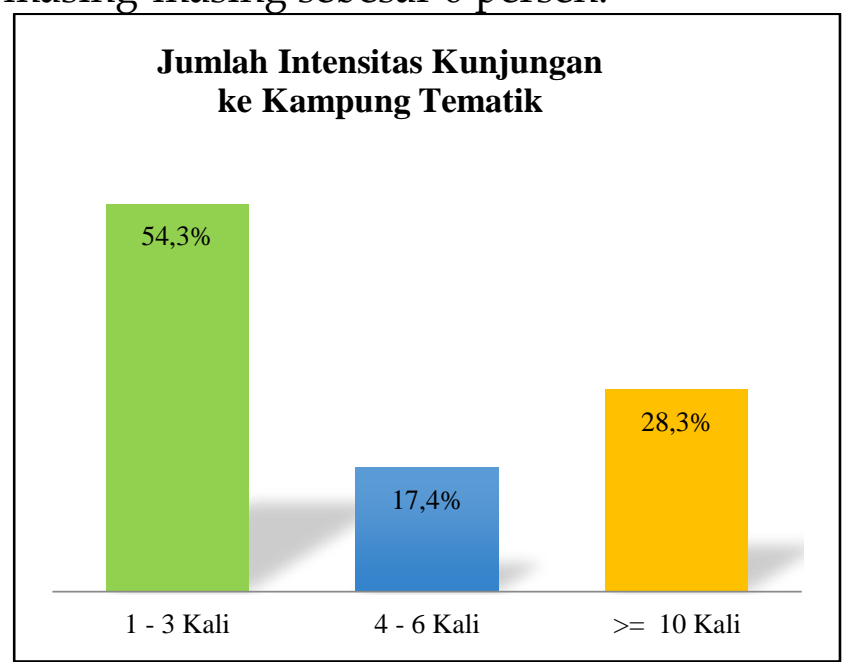

Gambar 12 Jumlah Intensitas Kunjungan ke Kampung Tematik

Sumber: Data Primer Diolah Penulis, 2019

Berdasarkan gambar 12 di atas dapat di artikan bahwa pengunjung kampung tematik berdasar jumlah intensitas kunjungan ke kampung tematik yang paling banyak, yaitu antara 1-3 kali sebesar 54,3 persen. Kemudian di atas 10 kali sebesar 28,3 persen, 4-6 kali sebesar 17,4 persen.

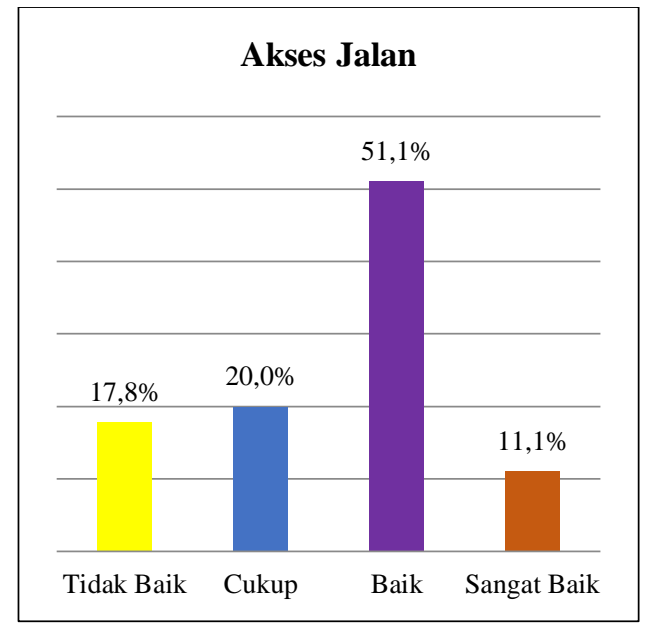

Gambar 13 Akses Jalan

Sumber: Data Primer Diolah Penulis, 2019

Berdasarkan gambar 13 di atas dapat di jelaskan bahwa pengunjung kampung tematik pada aksesibilitas: akses jalan yang paling banyak, yaitu baik sebesar 51,1 persen, sangat baik sebesar 11,1 persen, cukup sebesar 20 persen, dan tidak baik sebesar 17,8 persen. 


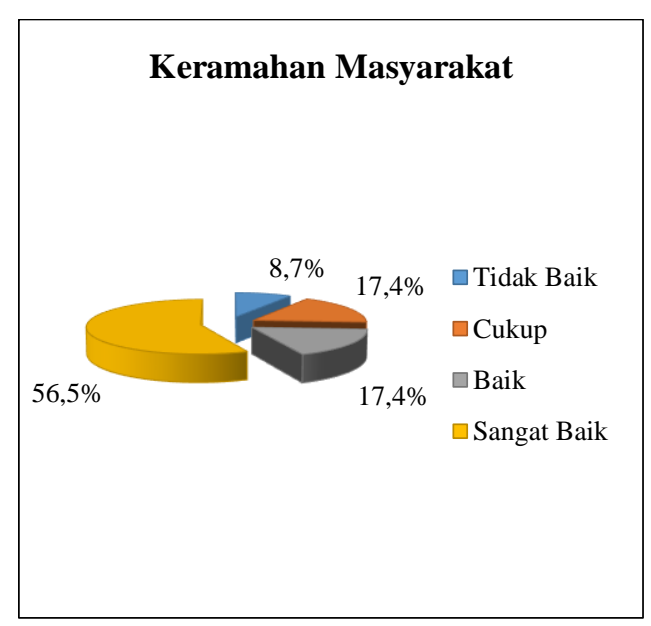

Gambar 14 Keramahan Masyarakat

Sumber: Data Primer Diolah Penulis, 2019

Berdasarkan gambar 14 di atas menggambarkan bahwa pengunjung kampung tematik untuk kriteria citra objek wisata: keramahan masyarakat yang tertinggi yaitu sangat baik sebesar 56,5 persen. Kemudian baik dan cukup masingmasing sebesar 17,4 persen, tidak baik sebesar 8,7 persen.

Perilaku Pengunjung

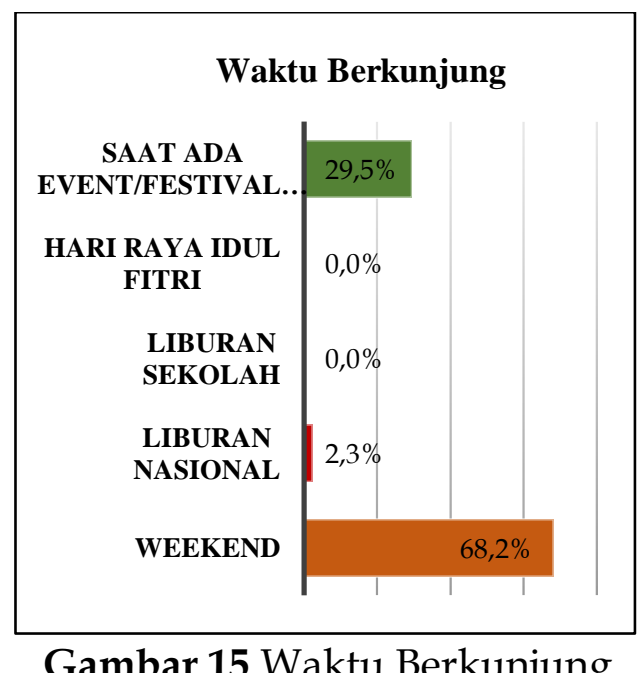

Gambar 15 Waktu Berkunjung

Sumber: Data Primer Diolah Penulis, 2019

Berdasarkan gambar 15 di atas menerangkan bahwa pengunjung kampung tematik pada kriteria waktu berkunjung ke kampung tematik paling banyak adalah weekend sebesar 68,2 persen. Kemudian saat ada event/festival wisata sebesar 29,5 persen, liburan nasional sebesar 2,3 persen. Sedangkan liburan sekolah dan hari raya Idul Fitri masing-masing sebesar 0,0 persen. 


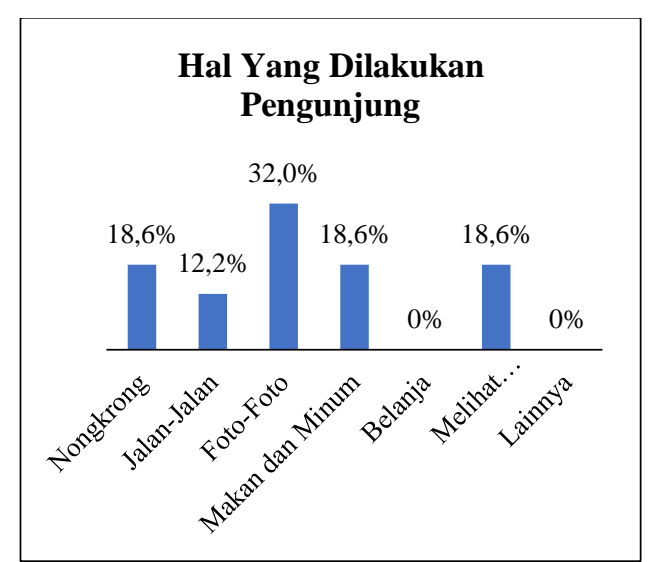

Gambar 16 Hal Yang Dilakukan Pengunjung

Sumber: Data Primer Diolah Penulis, 2019

Berdasarkan gambar 16 di atas menunjukkan bahwa pengunjung kampung tematik pada kategori hal yang dilakukan pengunjung di kampung tematik yang paling tinggi adalah foto-foto sebesar 32,0 persen. Selanjutnya melihat pemandangan, makan dan minum, nongkrong masing-masing sebesar 18,6 persen, jalan-jalan sebesar 12,2 persen, belanja dan lainnya masing-masing sebesar 0 persen.

\section{Pembahasan}

Hasil analisis data ditemukan bahwa berdasarkan alamat pengunjung, peminat yang berkunjung ke kampung tematik masih di dominasi oleh warga Tangerang. Eksistensi kampung tematik juga dapat dikatakan belum mampu menstimulasi pengunjung (wisatawan) dari luar daerah di Indonesia. Faktor ini harus menjadi perhatian sebab kampung tematik faktanya belum di kenal oleh publik secara luas, baik pada level masyarakat lokal, regional atau nasional. Meski demikian, kehadiran kampung tematik telah mampu mendorong minat pengunjung untuk datang, hal itu terbukti dari jumlah pengunjung laki-laki dan perempuan yang relatif seimbang. Namun jika memperhatikan status pernikahan ditemukan bahwa peminat yang paling tinggi untuk mengunjungi kampung tematik adalah pasangan yang sudah menikah, sementara yang berstatus belum menikah masih sangat rendah.

Fakta ini menarik sebab status single (belum menikah) sangat identik sebagai usia muda (milenial) yang memiliki preferensi-senang melakukan rekreasi ke tempat wisata dan mengeksplorasinya. Akan tetapi temuan data sebaliknya menyebutkan bahwa yang sudah menikah justru memiliki kecenderungan minat paling tinggi untuk mengunjungi kampung tematik. Jika melihat kepada kriteria usia, minat pengunjung yang datang ke kampung tematik cukup beragam. Para pengunjung berasal dari berbagai kelompok usia yang berbeda, hal ini jelas menunjukkan bahwa kehadiran kampung tematik disukai oleh berbagai segmen usia berbeda.

Dari segi kemampuan keluarga di dalam mengalokasikan anggaran biaya untuk rekreasi/wisata ditemukan fakta bahwa pengunjung yang datang ke kampung tematik memiliki variasi pengeluaran keluarga yang berbeda-beda, artinya jika melihat dari rata-rata status ekonomi pengunjung, ditemukan bahwa 
mereka adalah keluarga yang cukup mampu. Begitu halnya dengan pekerjaan dari pengunjung kampung tematik. Berdasarkan temuan di sebutkan bahwa mereka rata-rata memiliki pekerjaan tetap dan berasal dari berbagai latar belakang profesi kerja yang berbeda-beda. Fakta ini jelas mengindikasikan bahwa kampung tematik disukai oleh berbagai kalangan yang memiliki profesi pekerjaan berbeda.

Hasil penelitian ini menemukan bahwa kampung bekelir merupakan kampung tematik yang paling popular/dikenal dan banyak diketahui oleh pengunjung. Sebagai responden, pengunjung juga mengetahui lebih dari satu nama kampung tematik selain kampung bekelir, seperti kampung markisa, talas, grenpul, baca, harmonis, batik, hidroponik, rukun, hijau indah bersih, mural, ATM, anggur. Persepsi responden terkait dorongan/minat untuk mengunjungi kampung tematik juga ditemukan fakta bahwa kampung bekelir merupakan tempat yang paling diminati untuk di kunjungi, di susul kampung lainnya, seperti kampung harmonis, anggur, talas, mural, markisa, baca, batik, grenpul, hidroponik. Akan tetapi ditemukan fakta lain bahwa terdapat kampung tematik yang tidak diketahui, bahkan kurang diminati untuk dikunjungi, yaitu kampung hijau indah bersih, ATM, KPK, dan tidar.

Hal ini mengindikasikan bahwa kampung bekelir setidaknya sudah memiliki popularitas yang baik dan harus dipertahankan serta di tingkatkan. Lokasi kampung bekelir yang strategis dengan pesona eksotisme seni dan budaya yang ditawarkan serta didukung oleh lingkungan yang bersih cukup berhasil meningkatkan branding sehingga mampu menstimulasi masyarakat untuk berkunjung. Terdapat temuan lainnya yang mengatakan bahwa responden ratarata pernah berkunjung ke kampung tematik, seperti ke kampung bekelir, anggur, harmonis mural, markisa, talas, baca, grenpul, kampung hijau indah bersih, kampung batik, kampung hidroponik. Sedangkan yang lainnya, seperti kampung ATM, KPK, dan tidar tidak pernah mengunjungi.

Ketika di ditanya kampung tematik pilihan favorit, responden berpendapat bahwa kampung bekelir, anggur, harmonis, mural, talas, baca, markisa, batik sebagai lokasi favorit. Sementara kampung rukun, hijau indah bersih, ATM, KPK, tidar, grenpul, hidroponik tidak disebut sebagai pilihan favorit. Kemudian sejauh manakah responden mengaku puas terhadap kampung tematik, fakta menyebutkan hanya kampung markisa, harmonis, bekelir, baca, dan anggur yang dinilai memberikan kepuasan kepada pengunjung, sementara kampung lainnya tidak mendapat respon.

Fenomena ini menjelaskan bahwa meskipun masyarakat pernah berkunjung ke kampung tematik tetapi belum dapat di pastikan bahwa ia terdorong untuk berkunjung itu karena pilihan favorit, sebab fakta diketahui bahwa dari lima belas lokasi kampung tematik hanya terdapat delapan lokasi yang menjadi pilihan favorit. Bahkan, tidak semua yang menjadi pilihan favorit tersebut dapat memberikan kepuasan kepada pengunjung, terbukti dari delapan lokasi yang dinyatakan favorit hanya lima lokasi yang menurut responden memberikan kepuasan kepada pengunjung. 
Fakta menarik lainnya, yaitu meskipun kampung bekelir memiliki tingkat popularitas paling tinggi dan diminati, tetapi tingkat kepuasan pengunjung terhadap kampung bekelir masih rendah dibawah kampung markisa. Dengan begitu, dapat di simpulkan bahwa polarisasi dan manajemen pengembangan kampung tematik masih belum terorganisir dengan baik dan perlu langkah perbaikan. Temuan penelitian juga menemukan faktor yang mempengaruhi kedatangan ke kampung tematik. Menurut pendapat responden yang paling dominan berpengaruh, yaitu cerita dari teman/sahabat (word of mouth) dan informasi melalui situs berita. Sementara informasi di media cetak, media elektronik, sosial media, informasi di youtube, pameran/travel tidak memberikan pengaruh apapun.

Di dalam membangun branding peran media sangat penting. Tetapi hasil temuan diketahui bahwa media mainstream, media sosial dan event sponsorship belum secara optimal di gunakan untuk aktivitas promosi oleh penyedia jasa kampung tematik. Hal ini penting sebab ditemukan fakta bahwa faktor yang berpengaruh untuk datang ke kampung tematik tidak berasal dari media mainstream atau media sosial, melainkan dari word of mouth dan aspek situs berita. Sementara situs berita sifatnya news design bukan iklan promosi. Temuan lainnya terkait faktor yang menjadi keunggulan kampung tematik. Responden menyebutkan, yakni asik buat foto-foto, cocok untuk keluarga, tempat wisatanya unik, lokasi strategis, akses transportasi mudah, murah dan terjangkau, banyak viral di medsos, cocok buat melepas lelah, keamanan terjamin, pilihan oleh-oleh banyak dan faktor lainnya.

Hal ini menegaskan bahwa hampir semua item keunggulan kampung tematik di pilih responden. Artinya aspek-aspek keunggulan tersebut harus tetap di pertahankan, bahkan di tingkatkan untuk memberikan kepuasan kepada pengunjung. Pada sisi lain operator penyedia jasa harus mampu mencermati dan menggali aspek lain yang menjadi keunggulan kampung tematik. Ditemukan hal yang menjadi kelemahan kampung tematik menurut responden, yaitu susah mencari oleh-oleh, parkir susah, akses jalan susah, sering macet, kebersihan dan perawatan kurang, serta faktor lainnya. Pada item aspek ini penyedia jasa kampung tematik perlu memprioritaskan kebutuhan (needs) yang menjadi ekspektasi pengunjung, termasuk menelaah aspek kelemahan lainnya yang tidak diungkap oleh responden. Penyediaan seperti oleh-oleh dan fasilitas merupakan ciri penting dari sebuah daerah destinasi wisata.

Pada penelitian ini ditemukan bahwa intensitas jumlah kunjungan ke kampung tematik menurut responden cukup tinggi. Hal itu dilakukannya dalam kurun waktu 6 bulan terakhir. Tingginya frekuensi kunjungan terhadap kampung tematik merupakan potensi besar bagi pengembangan destinasi wisata kampung tematik. Maka dari itu, penting sebuah desain manajerial berbasis inovasi dan berorientasi pelanggan (wisatawan). Persepsi responden terhadap kampung tematik dari aspek: atraksi, fasilitas yang di kunjungi, aksesibilitas, citra objek wisata. Pada aspek atraksi ditemukan bahwa rata-rata pengunjung menyukai pemandangan kampung tematik, menyenangi kegiatan-kegiatan yang di adakan oleh kampung 
tematik dan menyukai souvenir sebagai cendra mata/oleh-oleh yang tersedia di kampung tematik. Atraksi sangat identik pada sebuah objek wisata, maka dari itu diperlukan skala prioritas untuk daya dukung ekowisata kampung tematik.

Temuan data tentang kesediaan fasilitas dinyatakan bahwa parkir; toilet; rumah makan; tempat ibadah menurut persepsi responden terletak pada proporsi antara representatif dan tidak representatif. Hal ini dapat di maklumi bahwa fasilitas yang seharusnya menjadi daya dukung di suatu kampung tematik dapat dikatakan belum ideal, bahkan di sebagian lokasi lainnya belum tersedia. Oleh karena itu, faktor yang menjadi penunjang vital seperti itu harus tersedia untuk memberikan rasa nyaman kepada pengunjung. Pada temuan aspek aksesibilitas akses jalan; kualitas jalan; transportasi umum; petunjuk jalan; responden secara umum memberikan apresiasi berimbang antara yang ideal dan kurang ideal. Hal ini bermakna bahwa pada prinsipnya akses yang menjadi fasilitas tersebut sejatinya sudah tersedia tetapi masih memiliki keterbatasan sehingga belum memenuhi harapan pengunjung. Oleh sebab itu, sarana vital yang berfungsi sebagai akses untuk menunju lokasi kampung tematik merupakan prioritas strategis di dalam pengembangan kampung tematik.

Hasil temuan di diperoleh aspek citra objek wisata: keramahan masyarakat; kebersihan lokasi; keamanan lokasi; berkunjung kembali merekomendasikan kepada orang lain; secara keseluruhan penilaian responden atas citra kampung tematik menujukkan apresiasi kelayakan dari sebuah objek wisata yang memiliki daya dukung ekowisata yang baik. Secara pskilogis karakteristik turis/wisatawan di mana pun sangat menyukai perangai ramah dari peribumi, semisal tempat wisata. Terlibih jika hal itu di dukung oleh kebersihan lokasi dan keamanan yang baik sehingga mampu memberikan kenyamanan kepada pengunjung. Kesan nyaman itu bahkan-akan terus di ingat di benak pikiran konsumen (pengunjung), hingga menancap di memori pikiran sampai kapan pun.

Sesuatu hal yang bisa menghadirkan sebuah new experience itu penting bagi orientasi bisnis jasa wisata seperti kampung tematik, sebab faktor inilah yang mendorong seorang wisatawan akan berkunjung kembali dan loyal, sehingga bertindak merekomendasikan lokasi wisata tersebut kepada orang lain untuk mencoba mengunjungi. Kepastian dan kemungkinan berkunjung kembali ke kampung tematik sesuai temuan menunjukkan respon yang sangat tinggi. Oleh karena itu, aspek-aspek yang terkait dengan citra objek wisata yang sudah baik harus tetap dipertahankan dan di tingkatkan. Hal itu penting dilakukan agar berbanding lurus, antara tingginya respon pengunjung untuk datang, dengan tingkat kepuasan atas citra objek wisata.

Temuan data di peroleh bahwa tidak semua waktu libur digunakan oleh pengunjung untuk berekreasi. Responden menilai waktu akhir pekan merupakan waktu paling tepat untuk berkunjung ke kampung tematik, terlebih di lokasi tersebut terdapat gelaran event/festival wisata. Pada momen tersebut pengunjung merasa nyaman apabila datang berkunjung bersama orang terdekat atau orang yang di cintainya. Mulai dari berkunjung sendiri, bersama teman, keluarga, suami/istri, keluarga besar dan komunitas. Pada momentum itu pun pengunjung 
lebih leluasa di dalam mengeksplorasi kehadirannya di kampung tematik. Ia bisa melakukan berbagai hal dengan beragam ekspresi, seperti melakukan foto-foto, melihat pemandangan, makan dan minum, nongkrong, dan jalan-jalan.

Dengan demikian, secara kriteria kampung tematik sudah bisa disebut sebagai tujuan destinasi wisata-yang setidaknya cukup memenuhi aspek-aspek pemenuhan kebutuhan perilaku wisatawan meskipun dengan segala keterbatasan. Hanya saja sebagai penyedia jasa kampung tematik belum secara optimal memanfaatkan momen seperti liburan nasional, sekolah atau hari raya sebagai ajang untuk menyedot wistawan. Untuk itu diperlukan langkah taktis agar momen liburan seperti itu dapat dimanfaatkan, di samping ajang kreativitas lainnya terutama memanfaatkan momen liburan reguler akhir pekan harus lebih menarik dan terus di tingkatkan untuk mendorong minat pengunjung sebanyakbanyaknya.

\section{KESIMPULAN}

Kampung tematik perlu melakukan strategi branding yang baik dan sekaligus mencari celah keunikan yang berfungsi sebagai pembeda sehingga memiliki marketable di pasar pariwisata. Kampung tematik sebagai target objek wisata perlu berupaya meningkatkan popularitas dan citra yang baik melalui promosi yang gencar/masif. Tiap-tiap kampung tematik harus dapat meningkatkan kualitas pelayanan yang optimal agar memberikan kepuasan kepada pengunjung secara merata di seluruh lokasi kampung tematik. Peran media cetak, elektronik dan media sosial harus di optimalkan dalam membangun "propaganda" promosi kampung tematik. Faktor yang menjadi keunggulan kampung tematik harus tetap di pertahankan dan perlu menggali aspek keunggulan lainnya. Faktor yang menjadi kelemahan kampung tematik harus di evaluasi dan di perbaiki agar memiliki kualitas daya saing yang kompetitif. Kampung tematik membutuhkan langkah inovasi dalam berbagai bidang, seperti atraksi; fasilitas; aksesibilitas; citra objek wisata. Memontum menjelang waktu liburan harus dimanfaatkan oleh kampung tematik untuk menyiapkan konsep-konsep kegiatan yang menarik.

\section{DAFTAR PUSTAKA}

Adikampana, I. M., Sunarta, I. N., \& Kerti Pujani, N. L. (2019). a Model of Community-Based Rural Tourism Products Development. Jurnal IPTA, 7(1), 83. https://doi.org/10.24843/ipta.2019.v07.i01.p11

Adityaji, R. (2018). Formulasi Strategi Pengembangan Destinasi Pariwisata Dengan Menggunakan Metode Analisis Swot: Studi Kasus Kawasan Pecinan Kapasan Surabaya. Jurnal Pariwisata Pesona, 3(1), 19-32. https://doi.org/10.26905/jpp.v3i1.2188

Akbar, T., \& Alfian, F. (2018). Kampung Tematik Sebagai Bentuk Partisipasi Masyarakat Dalam Permasalahan Permukiman Kumuh Di Kota Malang. Wahana, 70(2), 37-48. https://doi.org/10.36456/wahana.v70i2.1741

Bastian, A. F. (2018). Profil Visi \& Misi H. Arief R. Wismansyah \& H. Sachrudin Pasangan Calon Walikota \& Wakil Walikota Tangerang Periode 2018-2023. Tim 
Pemenangan Pasangan Calon Walikota \& Wakil Walikota Tangerang.

Bastian, A. F. (2019). Perencanaan Pembangunan Berdaya Saing. Forum Konsultasi Publik Rancangan Awal RPJMD Kota Tangerang, 2019-2023.

BPS. (2019). Statistik Kunjungan Wisatawan Mancanegara Tahun 2019 International Visitor Arrivals Statistics 2019. BPS RI/BPS-Statistics Indonesia.

Butowski, L. (2010). Tourism as a development factor in the light of regional development theories. Turyzm/Tourism, 20(1), 5-10. https:/ / doi.org/10.2478/v10106-010-0001-1

Cohen, L., Manion, L., \& Morrison, and K. (2007). Research Methods in Education (Sixth edit). USA and Canada by Routledge 270 Madison Avenue, New York, NY 10016.

Deni, F., \& Sopian, P. (2017). Peran Asean Tourism Forum Dalam Meningkatkan Pariwisata Indonesia Periode 2011-2015. International \& Diplomacy, 2(2), 279308. https:// doi.org/10.1017/CBO9781107415324.004

Fathorrazi, M., Diartho, H. C., \& Khoijah, M. (2019). Sub Sektor Pariwisata terhadap Pembangunan Daerah di Kabupaten Lumajang. Jurnal Penelitian Ilmu Ekonomi, 9(1), 43-47. https:// doi.org/10.30741/wiga.v9i1.367

Fosso, A., \& Kahane, R. (2013). Urban And Peri Urban Horticulture In Namibia. Acta Horticulturae, 821-827. https:/ / doi.org/10.17660/ ActaHortic.2013.1007.98

Fraenkel, J. R., Wallen, N. E., \& Helen H. Hyun. (1990). How to Design and Evaluate Research in Education. McGraw-Hill Companies, Inc., 1221 Avenue of the Americas, New York, NY 10020.

Goeldner, C. R., \& Ritchie, J. R. B. (2009). TOURISM Principles, Practices, Philosophies (Eleventh E). John Wiley \& Sons, Inc., Hoboken, New Jersey. Published simultaneously in Canada.

Hakim, L. (2010). Industri Pariwisata dan Pembangunan Nasional. Among Makarti, 3(5), 70-78. https://www.google.com/search?q=Hakim\%2C+L.+(2010).+Industri+Pariwi sata+dan+Pembangunan+Nasional.+Among+Makarti.+Vol.+3+(5)\%3A+7078.\&oq $=$ Hakim $\% 2 \mathrm{C}+$ L. $+(2010) .+$ Industri + Pariwisata + dan + Pembangunan $+\mathrm{N}$ asional.+Among+Makarti.+Vol.+3+(5)\%3A+70-78.\&aqs=chrome..69i5

Idziak, W., Majewski, J., \& Zmyślony, P. (2015). Community participation in sustainable rural tourism experience creation: a long-term appraisal and lessons from a thematic villages project in Poland. Journal of Sustainable Tourism, 23. https://doi.org/10.1080/09669582.2015.1019513

Imran, D. S., \& Mbulu, Y. P. (2020). Partisipasi Masyarakat dalam Kreativitas Pengembangan Wisata Kampung Tematik (Studi Kasus: Kampung Pulo Geulis, Kota Bogor, Jawa Barat). Fakultas Pariwisata, Universitas Pancasila, 8(1), 11-22.

http://journal.univpancasila.ac.id/index.php/jtda/article/view/1407/952 Inskeep. (1998). Guide for local Authorities on Developing Sustainable Tourism. World Tourism Organization, New York.

Kłoczko-Gajewska, A. (2014). General Characteristics of Thematic Villages in 
Poland. Visegrad Journal on Bioeconomy and Sustainable Development, 2(2), 60-63. https://doi.org/10.2478/vjbsd-2013-0012

Kotler, P. (2005). Manajemen Pemasaran (Jilid I da). PT. Indeks.

Kristiana, E., \& Kusumoarto, A. (2019). Penataan Kampung Babakan Siliwangi

Sebagai Kampung Tematik Wisata. Simposium Nasional Ilmiah, 1146-1155. https://doi.org/10.30998/simponi.v0i0.445

Leiper, N. (2004). Tourism Management (3rd Editio). New South Wales: Pearson Education Australia.

MacMillan, J. H. and, \& Schumacher, S. (2001). Research in Education. A Conceptual Introduction. 5th Edition, Longman, Boston.

Putri, D. H., \& Pawestri, T. A. (2019). the Study of Malang Thematic Kampong As a Potential International Tourism Destination With the Genius Loci Concept. Arsitektura, 17(1), 87. https://doi.org/10.20961/arst.v17i1.29118

Putri, L. Y., \& Pigawati, B. (2019). Wisata Budaya Kampung Jawi Di Kota Semarang Berdasarkan Aspek Permintaan Dan Penawaran. Jurnal Pembangunan Wilayah $\mathcal{E}$ Kota, 15(3), 248-261. https:// doi.org/10.14710/pwk.v15i3.22154

Resnawaty, R. (2016). Strategi Community Practice Dalam Pengembangan Pariwisata Berbasis Masyarakat. Share: Social Work Journal, 6(1). https://doi.org/10.24198/share.v6i1.13152

Sabon, V. L., Perdana, M. T. P., Koropit, P. C. S., \& Pierre, W. C. D. (2018). Strategi Peningkatan Kinerja Sektor Pariwisata Indonesia Pada ASEAN Economic Community. Jurnal Bisnis Dan Manajemen, 8(2), 163-176. https:// doi.org/10.15408/ess.v8i2.5928

Slabbert, E. (2015). Travel Motivations And Behaviour Of Tourists To A South African. Book of Proceedings Vol. I - International Conference on Tourism $\mathcal{E}$ Management Studies - Algarve 2011, September.

Solimun, Armanu dan Fernandes, A. A. R. (2018). Metode Penelitian Kuantitatif: Perspektif Sistem. Mengungkap Novelty dan Memenuhi Validitas Penelitian. UB Press, Malang, Indonesia.

Tamara, A. P. (2018). Kajian Pelaksanaan Konsep Kampung Tematik di Kampung Hidroponik Kelurahan Tanjung Mas Kota Semarang. Jurnal Wilayah Dan Lingkungan, 6(April), 40-57. https://doi.org/10.14710/jw1.6.1.40-57.

Ujianto, B., \& Zahro, H. (2018). Kegiatan Perancangan Kampung Belimbing RW.0809, Kel. Blimbing, Kec. Blimbing, Kota Malang. Pawon: Jurnal Arsitektur, 2, 5772. https://doi.org/10.36040/pawon.v2i02.254

Vana, M. V., \& Malaescu, S. (2016). Cultural Thematic Tourism Itineraries: Mediators of Success. Procedia Economics and Finance, 39(November 2015), 642652. https://doi.org/10.1016/s2212-5671(16)30311-2

Vanderstoep, S. W. \& D. J. J. (2009). Research Methods for Everyday Life: Blending Qualitative and Quantitative Approaches. San Fransisco: John Wiley \& Sons.

Wismansyah, A. R. (2020). Kawal dan Dukung Kampung Tematik di Kota Tangerang. Pelita Banten. https://www.pelitabanten.com/52857/2020/01/23/ariefkawal-dan-dukung-kampung-tematik-di-kota-tangerang/

Wiweka, K., Wachyuni, S. S., Rini, N. A., Adnyana, I. N., \& Adnyana, P. P. (2019). 
Perilaku Berwisata Wisatawan Generasi Milenial Di Jakarta Pada Era Revolusi Industri 4.0. Jurnal Sains Terapan Pariwisata, 4(3), 313-334.

Zikmund G, W. (1997). Business Research Method (5th ed). New York: Dryden Press. 